\title{
Electrochemical Energy Storage
}

\author{
Pier Luigi Antonucci and Vincenzo Antonucci \\ Mediterranea University of Reggio Calabria, \\ CNR Institute for Advanced Energy Technologies, \\ Italy
}

\section{Introduction}

The problems related to the differed time between production and use of electrical energy produced by renewable sources makes storage systems an integral part of Renewable Energy Sources (RES), especially for stand-alone systems. Furthermore, for grid-connected systems, the stability of the electric system and the quality and stability of the delivered voltage will result in a high quality system in the presence of intermediate storage. Storage systems are particularly onerous for RES and, as a consequence, their cost and life-time significantly affect the total cost of the whole system.

The relation between technical and economical characteristics in terms of dimension and technology to be employed has to be singled-out and optimized depending on the circumstances and, for different applications, in terms of release time of the stored energy and outbound power.

The alternatives to obtain a continuous, reliable and cost-effective availability of electricity include:

- diffusion of RES, production from clean carbon technologies and others sources

- technical evolution of the transmission grid for the connection of these sources to the loads

- programs to meet power/energy demands and management of the loads.

The diffusion of storage technologies in the public grid include several benefits:

- the optimization of the grid for the fulfilment of base-load

- the way to facilitate the power trade-off in RES systems fluctuating over time or available only during day-time

- $\quad$ easy integration in grid of the energy requirements for hybrid vehicles

- the chance of investments differentiation in the distribution grid to be adapted to temporary peak-loads.

- $\quad$ resources for the provision of auxiliary services directly to the electricity provider.

The different storage technologies can be classified on the basis of the different methodologies utilized:

- mechanical (compressed air energy storage, flywheels)

- electrochemical (lead-, nickel-, high temperature salts-, redox-batteries, hydrogen.

- electrical (capacitors, supercapacitors).

Although some storage technologies could work for several applications, the most part of the different options is not economically applicable to different functional categories. Their 
assessment must be done on the basis of several parameters which establish their applicability:

- power level (nominal, pulsed)

- $\quad$ energy storage level (at different charge and discharge rates)

- memory effect

- power density

- energy density

- $\quad$ overall cycle efficiency

- life-time (number of cycles and performance)

- operative characteristics

- environmental impact (LCA)

- $\quad$ recycle opportunity and costs

- $\quad$ investment costs

- maintaining costs

\begin{tabular}{|c|c|c|c|}
\hline Technology & State of the art & $\begin{array}{c}\text { Short term } \\
\text { application }\end{array}$ & $\begin{array}{c}\text { Medium term } \\
\text { application }\end{array}$ \\
\hline Lead acid, NiCd & $\begin{array}{c}\text { Commercially } \\
\text { available }\end{array}$ & $\begin{array}{c}\text { Off grid } \\
\text { demonstration }\end{array}$ & Niche markets \\
\hline HT batteries & $\begin{array}{c}\text { Commercially } \\
\text { available }\end{array}$ & Demonstration & $\begin{array}{c}\text { Probable, potentially } \\
\text { with PV }\end{array}$ \\
\hline Redox batteries & Lab prototypes, dem & Dev \& demonstration & Probable \\
\hline Lithium batteries & Lab prototypes, dem & Dev \& demonstration & Probable \\
\hline Hydrogen & $\begin{array}{c}\text { Lab prototypes \& } \\
\text { dem }\end{array}$ & Demonstration & $\begin{array}{c}\text { Possible, niche } \\
\text { applications }\end{array}$ \\
\hline Capacitors & $\begin{array}{c}\text { Near to the market } \\
\text { (small size) }\end{array}$ & $\begin{array}{c}\text { Required } \\
\text { development }\end{array}$ & $\begin{array}{c}\text { Possible attainment of } \\
\text { commercial targets }\end{array}$ \\
\hline
\end{tabular}

Table 1. Technological and commercial maturity of the different technologies is summarized

\begin{tabular}{|c|c|c|}
\hline Technology & Commercial maturity & Costs \\
\hline \multicolumn{3}{|l|}{ Lead acid } \\
\hline $\mathrm{Ni}-\mathrm{Cd}$ & $\Delta$ & $\Delta$ \\
\hline $\mathrm{Ni}-\mathrm{Mh}$ & $\Delta$ & $\Delta$ \\
\hline \multicolumn{3}{|l|}{$\mathrm{Na} / \mathrm{S}$} \\
\hline ZEBRA & & $\Delta$ \\
\hline $\mathrm{Zn} / \mathrm{Br}$ & & $\Delta$ \\
\hline Lithium ion & & $\Delta$ \\
\hline $\operatorname{Redox}(\mathrm{V})$ & & $\Delta$ \\
\hline Supercap & $\Delta$ & $\Delta$ \\
\hline RFC & & \\
\hline
\end{tabular}

Table 2. State of the art of electrochemical technologies 


\begin{tabular}{|c|c|c|}
\hline Symbol & Commercial maturity & Costs \\
\hline & $\begin{array}{c}\text { Mature product, several units } \\
\text { sold }\end{array}$ & Price list available \\
\hline & Commercial product & Prices on request \\
\hline & $\begin{array}{c}\text { Prototypes under construction } \\
\text { tests in progress }\end{array}$ & Defined per single project \\
\hline & Only projects available & Estimated \\
\hline
\end{tabular}

Table 2. State of the art of electrochemical technologies (continuation)

This chapter deals with the analysis of electrochemical technologies for the storage of electricity in stationary applications able to meet present and future challenges for the three following goals:

- Power quality: stored energy to be delivered for seconds in order to guarantee the continuity of stabilized electricity supply

- Bridging power: energy furnished for minutes to guarantee the continuity of the service during the transition from an energy source to another one.

- Energy management, for the time-lag between the production and the utilization of the produced energy. A typical utilization is the optimization of the load level when the energy cost is low and utilization when the cost from the grid is high.

- $\quad$ (Antonucci P.L., 2010, Antonucci V., 2011, Strbac G. \& Black M. 2004, Stuntz. L, 2004., Makansi J. \& Abboud J, 2002).

\begin{tabular}{|c|c|c|}
\hline Application & Power & Energy \\
\hline Domestic & $1 \mathrm{~kW}$ & $5 \mathrm{kWh}$ \\
\hline Commercial & $10-100 \mathrm{~kW}$ & $25 \mathrm{kWh}$ \\
\hline Distribution grid & $10-100 \mathrm{MW}$ & $10-100 \mathrm{MWh}$ \\
\hline
\end{tabular}

Table 3. Typical intervals and parameters of the different applications

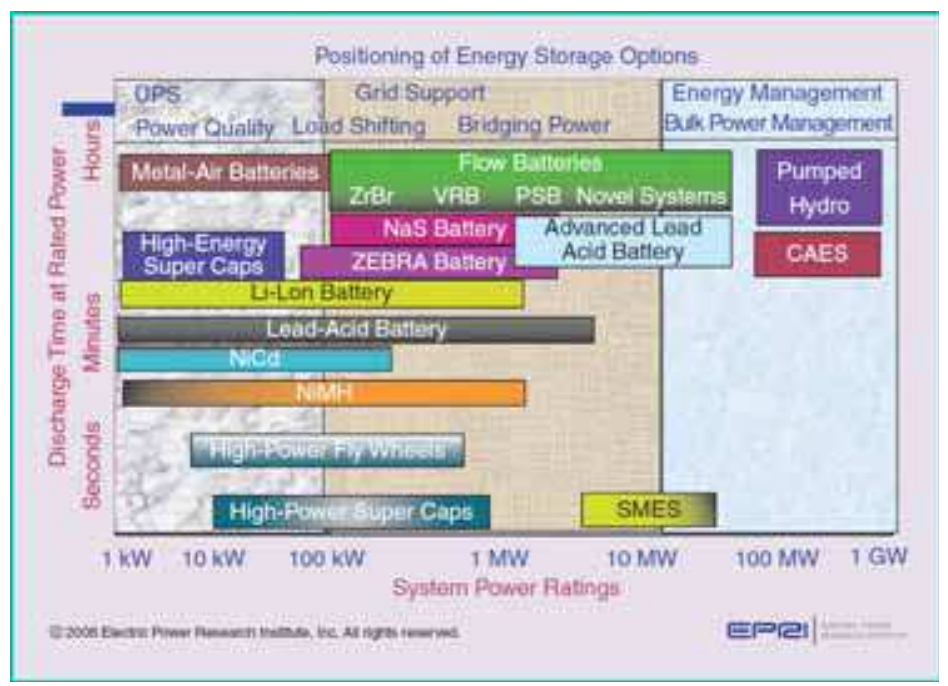

Fig. 1. The state of the art of storage technologies (source: EPRI) 
At present, the most common electrochemical storage technology is represented by leadacid batteries. In USA the current market of lead-acid batteries for commercial, industrial and automotive applications is about 3 billion dollars per year, with an annual rate of growth of $8.5 \%$.

For what concerns the most recent applications (distributed generation, peak shawing, power quality), the use of lead-acid batteries has been widely demonstrated, but costs and life-cycle characteristics are not satisfactory for these applications, characterized by high number of cycles.

On the other hand, the use of $\mathrm{Li}$ ions batteries for mobile applications is rapidly increasing, with an annual growth rate of 50-60\%. For stationary applications (in particular, for mitigation of the variability of renewable sources), their potential has not yet been thoroughly explored, as well as their cost-effectiveness, except for some auxiliary storage systems.

Others electrochemical technologies for backup systems include sodium-sulfide, zincbromide and redox vanadium batteries. The sodium sulphur and zinc bromide technologies are rapidly expanding in Japan and USA. Nickel cadmium and Nickel MH are used in power backup systems.

The pressing demand of better storage technologies have produced incentives to the R\&D sector and financing through venture capital. In this regard, R\&D is addressed to a baseelectrochemistry level in order to single-out the combinations of chemicals having the maximum potential in energy storage systems.

\section{Batteries}

Batteries are devices that convert the chemical energy contained in an electrochemically active material directly into electrical energy by means of a redox reaction. For a rechargeable system, the battery allows to store a defined amount of chemical energy and can be re-charged when the electrochemically active material has been transformed.

They are the most established way of storing electricity. Several types of rechargeable systems exist, from the mature lead acid to different newer technologies at various developmental stages.

Recently, new demands of portable and transport applications, as well as of power electronics and use of large scale systems for utility applications have determined further, dramatic development of new battery technologies.

\subsection{Lead acid}

Lead acid represent more than $90 \%$ of the whole batteries market. Main constituents are the lead negative electrode, the lead dioxide positive one and the separator, with sulphuric acid as the electrolyte. The flooded type requires the filling up with distilled water, whereas the sealed, maintenance-free type has an absorbed electrolyte.

At present, typical lead batteries for transportation have a polypropilene external case, high performance separators based on glass fibre, polyethylene or polyvinyl chloride matrices, thin grids with extremely low $\mathrm{Sb}$ content or based on $\mathrm{Pb}-, \mathrm{Ca}-, \mathrm{Sn}-\mathrm{Al}$ alloys. The effect of additives has been investigated and optimized, allowing to reduce or cancel the necessity of maintenance.

The continuous development of the technology has caused important improvements in its capabilities, resulting in low costs and high reliability. The main drawback remains, however, its low energy density due to the high density of lead.

The so-called "advanced lead" uses carbon additives in the negative electrode in order to increase its life-time; this type is still at a developmental stage. 
The trend to produce lead batteries having superior performance, cyclability characteristics and life-time are dictated by the increasing demand of electrical energy for distributed generation, for hybrid vehicles, for auxiliaries in internal combustion engines. Future lead batteries will be characterized by the use of new materials with impact on the design, recovery, recycle, disposal and refining. The optimization of the whole cycle including production, use, recovery and recycle, driven by an appropriate life-cycle analysis, will be of fundamental importance.

\subsection{Nickel Cadmium}

Nickel-Cadmium (Ni-Cd) batteries represent a good compromise between specific energy, specific power, life cycle and reliability. They are constituted by a positive plate of nickel oxy-hydroxide $(\mathrm{NiOOH})$, a negative one of cadmium $(\mathrm{Cd})$ and an aqueous solution of potassium hydroxide $(\mathrm{KOH})$ as the electrolyte. During discharge $\mathrm{NiOOH}$ is converted to $\mathrm{Ni}(\mathrm{OH})_{2}$, which is restored during charge. $\mathrm{Cd}$ is converted to $\mathrm{Cd}(\mathrm{OH})_{2}$ during discharge, and is restored during charge. The toxicity of $\mathrm{Cd}$ has led to the development of $\mathrm{Ni}-\mathrm{MH}$ batteries, based on metal hydrides. These are similar to the $\mathrm{Ni}-\mathrm{Cd}$, the main difference being the composition of the negative plate made of hydrogen adsorbed on a metallic alloy. This can be of the type AB5 (mixture of nickel and rare earths) and AB2 (mixture of nickel and titanium, vanadium and zirconium). This type of battery is at present used in some hybrid vehicles.

Two designs have been developed for this technology, namely the pocket plate and the sintered plate. In the first, the active material is held between steel plates; the sintered plate configuration uses different materials as current collector, and the active substance is sintered onto these. The manufacturing process is more expensive than for lead acid, resulting in a higher cost for this technology. Furthermore, this suffers from "memory effect", resulting in a full charge only after a series of full discharges. This effect can be mitigated by an appropriate management procedure. A significant advantage over lead acid is represented the lower maintenance requirements.

\subsection{Lithium ion}

Historically, Li-ion were the first $\mathrm{Li}$ batteries developed for portable electronics (cellular phones, cordless, notebooks). They have the highest power density of commercial batteries.

The anode is made of metallic $\mathrm{Li}, \mathrm{Li}$ alloys or $\mathrm{Li}-\mathrm{C}$ intercalation compounds. The electrolyte is based on non aqueous compounds, such as $\mathrm{LiClO} 4$ or LiPF6. The next generation batteries will use a polymer electrolyte containing Li dissolved in a polar polymer such as polyethylene oxide (PEO). The cathode is made of intercalation structures containing void channels or layers, able to accept $\mathrm{Li}$ ions, and a mixed valence in the host framework, able to receive or give electrons. $\mathrm{TiS}_{2}$ has such a structure; it is able to receive $\mathrm{Li}$ ions in the void spaces separating the $\mathrm{TiS}_{2}$ adjacent layers. To maintain the electroneutrality electrons must enter into the material. The intercalation reaction can be so written:

$$
\mathrm{Ti}_{4}+\mathrm{S}_{2}+x \mathrm{Li}=\mathrm{Li}+x \mathrm{Ti}_{4}+1-x \mathrm{Ti}_{3}+x \mathrm{~S}_{2}
$$

Many others intercalation compounds can work as a cathode. The most commercially diffused is $\mathrm{LiCoO}_{2}$, which has alternated layers of $\mathrm{Li}$ and $\mathrm{Co}$ ions in octahedral sites inside the cсp lattice of the oxide ions. The $\mathrm{LiCoO}_{2}$ formula is referred to the completely intercalated form when the battery is discharged. During recharging $\mathrm{Li}$ ions are removed and the oxidation of $\mathrm{Co}^{3+}$ to $\mathrm{Co}^{4+}$ occurs. The $\mathrm{Co}^{3+} / \mathrm{Co}^{4+}$ couple supplies a cell voltage of about $4.0 \mathrm{~V}$ vs. metallic Li. 
New configurations have been developed for stationary applications, with titanate at the anode and manganese at the cathode. Cost is at present very high; its reduction is linked to an eventual increase in production. Current energy density values reach $175 \mathrm{Wh} / \mathrm{kg}$, with cycle lives as high as 20,000 cycles.

Recently, great interest has raised for sustainable mobility (HEVs, EvS, HEV\&FC, scooters, motorcycles, electrical bicycles). In spite of a remarkable growth of the market, the scientific development of Li-ion batteries is often exposed to criticism because of its slow development in comparison with other technologies like semiconductors. The world market of Li-ion batteries is controlled by a limited number of great companies, most of which located in Asia (Japan, China, Korea, more than $90 \%$ of those commercialized in the world). The main users (Europe and USA) produce only $5-10 \%$ worldwide, USA being leader in R\&D due to projects funded by DoE, NIST and DoD (Fig.2).

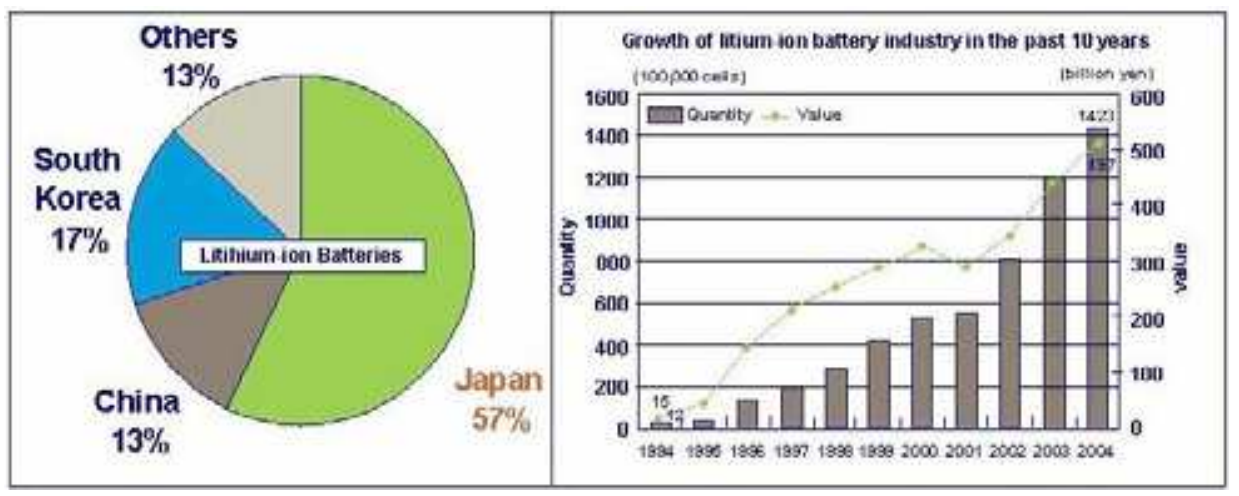

Fig. 2. World production of Lithium batteries

Fig. 3 shows the market trend of Li batteries from 2004 to 2012. The yearly growth is $15-20 \%$, with even more promising scenarios in the case of introduction of HEV into the global market. Fig. 4 shows the market trend of conversion and storage of energy (source: Lux Research, 2008). Its value in 2011 is about 50 bln dollars (10 bln for Li batteries only, 20 bln for lead and 2 bln for NiMH).

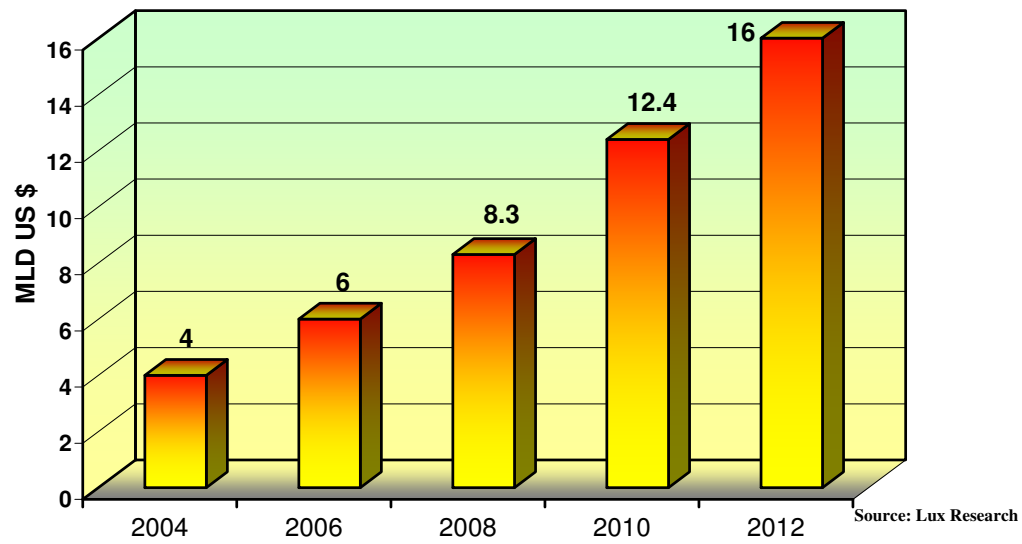

Fig. 3. World market of Lithium batteries 


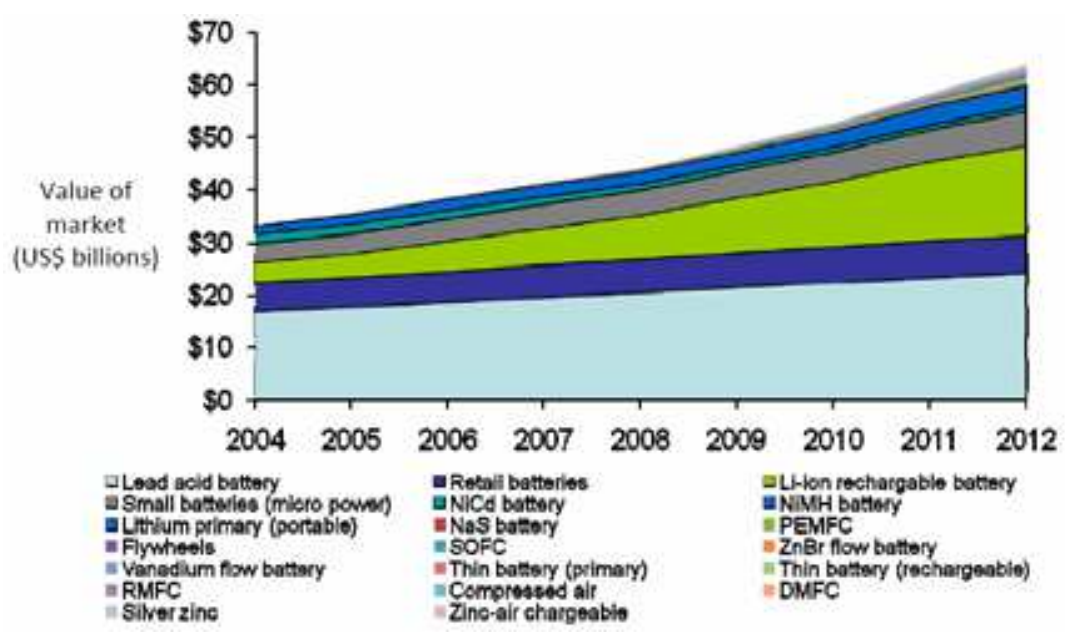

Fig. 4. Storage systems: world market values

\subsection{High temperature batteries}

\subsubsection{Sodium sulphur}

The battery consists in a positive electrode constituted by fused sulphur and a negative one of fused sodium separated by a ceramic electrolyte (sodium ions of beta alumina). The discharge process consists in the formation of sodium sulphide (sodium ions cross the electrolyte and the electrons go to the external circuit). The process is obviously reversible (charge phase). The discharge reaction is: $2 \mathrm{Na}+\mathrm{xS}=\mathrm{Na}_{2} \mathrm{Sx}$, where $\mathrm{x}$ is dependent on the charge level of the cell. During the first steps of the discharge process, $x$ is estimated to be equal to 5 , approximately corresponding to the sodium sulphide formula more rich in sodium, $\mathrm{Na}_{2} \mathrm{~S}_{5}$. The OCV depends on the charge level and on the temperature (max value: $2.08 \mathrm{~V}$ ).

The working temperature is about $300^{\circ} \mathrm{C}$. This results in improved performance in comparison with room temperature systems, requiring yet efficient insulation to prevent heat losses, as well as a heat source using the stored energy of the battery itself. As no selfdischarge occurs, efficiencies near $90 \%$ are usually reached. Yet, they have room for further development.

\subsubsection{Sodium nickel chloride}

Sodium-nickel chloride batteries ("ZEBRA", Zero Emission Battery Research Activity) possess a high energy density $(120 \mathrm{Wh} / \mathrm{kg})$ with high performance $(180 \mathrm{~W} / \mathrm{kg})$. The operation temperature range is $270-350^{\circ} \mathrm{C}$; they work in a thermal chamber. The nickel chloride allows high capacity (500 Ah). Furthermore, the solid electrolyte allows tolerance towards possible short circuits and self-discharge. The substitution of fused nickel chloride with fused iron chloride would make the system more promising but, to maintain $\mathrm{FeCl}_{2}$ in the fused state, the cathode $\left(\mathrm{Fe} / \mathrm{FeCl}_{2}\right)$ has to be impregnated with fused $\mathrm{NaAlCl}_{4}$. The reactions occurring in the cell are:

$$
\begin{array}{ll}
2 \mathrm{Na}+\mathrm{NiCl}_{2}=2 \mathrm{NaCl}+\mathrm{Ni} \quad \mathrm{E}=2.58 \mathrm{~V} \\
2 \mathrm{Na}+\mathrm{FeCl}_{2}=2 \mathrm{NaCl}+\mathrm{Fe} & \mathrm{E}=2.35 \mathrm{~V}
\end{array}
$$


In comparison with sodium sulphur they have better safety characteristics and higher cell voltage. The disadvantages consist in the actual lower energy and power density.

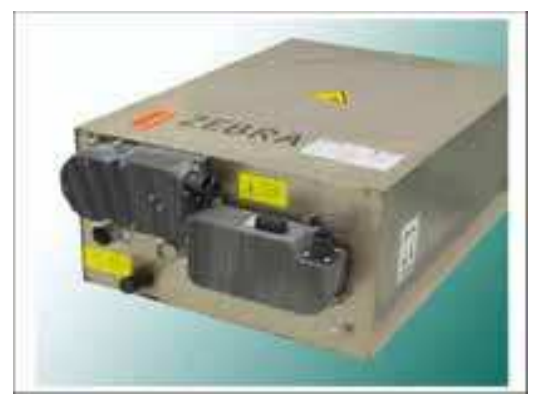

ocv 2.58 at $300^{\circ} \mathrm{C}$.

Operating range

$270^{\circ} \mathrm{C}$ to $350^{\circ} \mathrm{C}$.

Typical capacity 32Ah

$100 \%$ Ah-efficiency

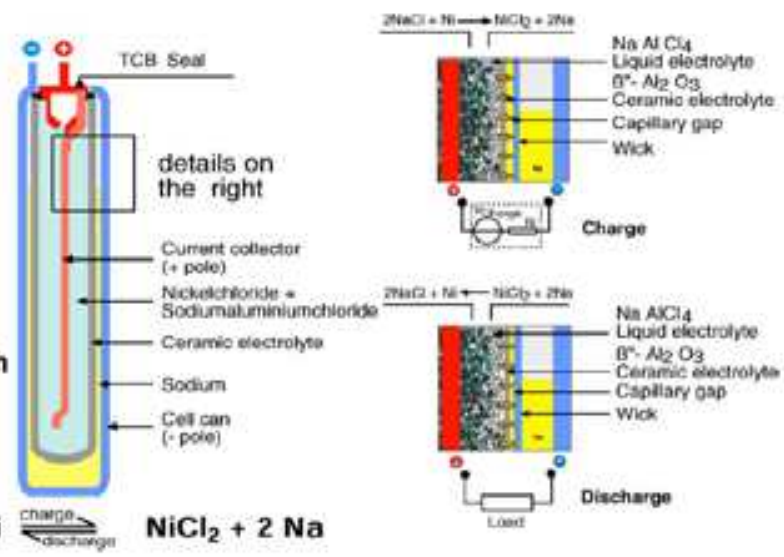

Fig. 5. Zebra battery

\section{Electrochemical flow (redox) cell systems}

Flow or redox batteries are electrochemical devices halfway between secondary batteries and fuel cells. The energy is stored in two electrolytes, separated by an ion exchange membrane. There is no electrochemical reaction between the electrolytes and the electrodes. They can supply power as long as they are supplied with electrolytes.

There is a conceptual difference between power and energy properties. The delivered power depends upon electrodes dimension and number of cells, whereas the storage capacity is determined by the volume of the reservoirs that contain the electrolytes flowing through the cells. For a given power absorption, the energy capacity can be increased by introducing more electrolyte (that is, using more capacious reservoirs). Therefore, flow batteries are particularly advantageous for high energy (long term) applications, when several hours of storage are required. The recharge capacity is equivalent to the rapidity of refilling, therefore this kind of battery appears particularly promising for mobile applications. Compared to other types of batteries, redox systems have an outstandingly long life (unlimited in theory) and no operative limitations (no memory effects or problems connected with discharge). 


\subsection{Vanadium Redox Battery (VRB)}

The vanadium technology is based on the four oxidation states of $\mathrm{V}$, exploiting the $\mathrm{V}^{2+} / \mathrm{V}^{3+}$ transition one side of the membrane and the $\mathrm{V}^{5+} / \mathrm{V}^{4+}$ transition of the other. The use of $\mathrm{V}$ sulphates or, more recently, $\mathrm{V}$ halides on both sides considerably simplifies the electrolyte management.

Reactions occurring during charging and discharging are:

$$
\begin{aligned}
& \mathrm{V}^{4+} \underset{\text { discharge }}{\stackrel{\text { charge }}{\rightleftarrows}} \mathrm{V}^{5+}+\mathrm{e}- \\
& \mathrm{V}^{3+}+\mathrm{e}-\underset{\text { discharge }}{\stackrel{\text { charge }}{\rightleftarrows}} \mathrm{V}^{2+}
\end{aligned}
$$

VRB can be suitable for different applications, such as enhanced power quality, UPS, peak shaving, increased security of supply and integration with RES. Due to their low energy density, major development is addressed to stationary applications.

\subsection{Zinc bromine}

The negative zinc electrode and the positive bromine electrode are separated by a microporous separator. Circulation of zinc solution and bromine compounds occurs through the two cell compartments from the respective reservoirs. In the charging phase zinc is electroplated on the cathode while bromine evolves at the anode and stored at the bottom of the positive electrode reservoir. On discharge, zinc is oxidized to its ions, while bromine reduces to bromide ions.

$$
\begin{array}{ll}
\text { Positive electrode: } & 2 \mathrm{Br}^{-} \stackrel{\text { charge }}{\stackrel{\text { discharge }}{\rightleftarrows}} \mathrm{Br}_{2}+2 \mathrm{e}- \\
\text { Negative electrode: } & \mathrm{Zn}^{2+}+2 \mathrm{e}-\underset{\text { discharge }}{\stackrel{\text { charge }}{\rightleftarrows}} \mathrm{Zn}
\end{array}
$$

Discharge times range from few seconds up to several hours. Demonstration projects are primarily focused to on-grid utility applications for load levelling and RES optimization.

\subsection{Polysulphide bromide (Regenesys ${ }^{\mathrm{TM}}$ )}

This system utilizes the reversible electrochemical reaction between two salt electrolyte solutions:

$$
3 \mathrm{NaBr}+\mathrm{Na}_{2} \mathrm{~S}_{4} \text { (charging) } \leftrightarrow 2 \mathrm{Na}_{2} \mathrm{~S}_{2}+\mathrm{NaBr}_{3} \text { (discharging) }
$$

Previously developed over the past fifteen years, the system has been marketed as a gridlinked utility storage system for more than 5 MWe. Actually, no development or commercialization programs are foreseen.

\section{Hydrogen storage systems}

The storage of electricity is feasible by producing hydrogen through water electrolysis. The as produced hydrogen is stored in compressed gas or liquid form or through solid 
adsorption at low pressure. The system is constituted by an electrolyzer with a fuel cell, separated, or by a regenerative electrolyzer, which works as EL or FC by inverting the polarity. Such an approach allows a direct integration of distributed generation from RES with zero impact mobility.

Advantages of hydrogen-based storage systems include: i) the high energy density of hydrogen; ii) the possibility of realizing systems over a large size range (multi kW to MWs); modularity; environmental benignity. Main disadvantages are represented by the high cost and low round-trip efficiency.

\subsection{Regenerative electrolyzers}

Regenerative or reversible cells (RFC) are electrochemical systems able to both convert chemical to electrical energy (fuel cell mode) and carry out the reverse process, that is to dissociate the water molecule into hydrogen and oxygen (electrolyzer mode). They are composed of two distinct sections, with electrodes dedicated to only one function; in particular, the oxygen-side electrodes have different catalysts, generally platinum for oxygen reduction in the fuel cell section and a metal oxide for water ionization in the electrolyzer section.

Differently, Unitized Reversible Cells (URFC) combine the two functions in an unique device; in this case, the oxygen electrode contains both catalysts for water ionization and oxygen reduction. Also the flow-field, supported by conductive plates, must be able to operate both for gas evolution and electricity production.

Both RFC and URFC are used when the characteristics of rechargeable batteries $(\mathrm{Pb}, \mathrm{Li}$, $\mathrm{NiMH}$ ) are needed; for example, in stationary plants for power generation connected to wind or photovoltaic systems, in the automotive, aeronautic or space sectors. In all cases, duty of the cells is to store the energy coming from an external source in the form of hydrogen and to return it when needed.

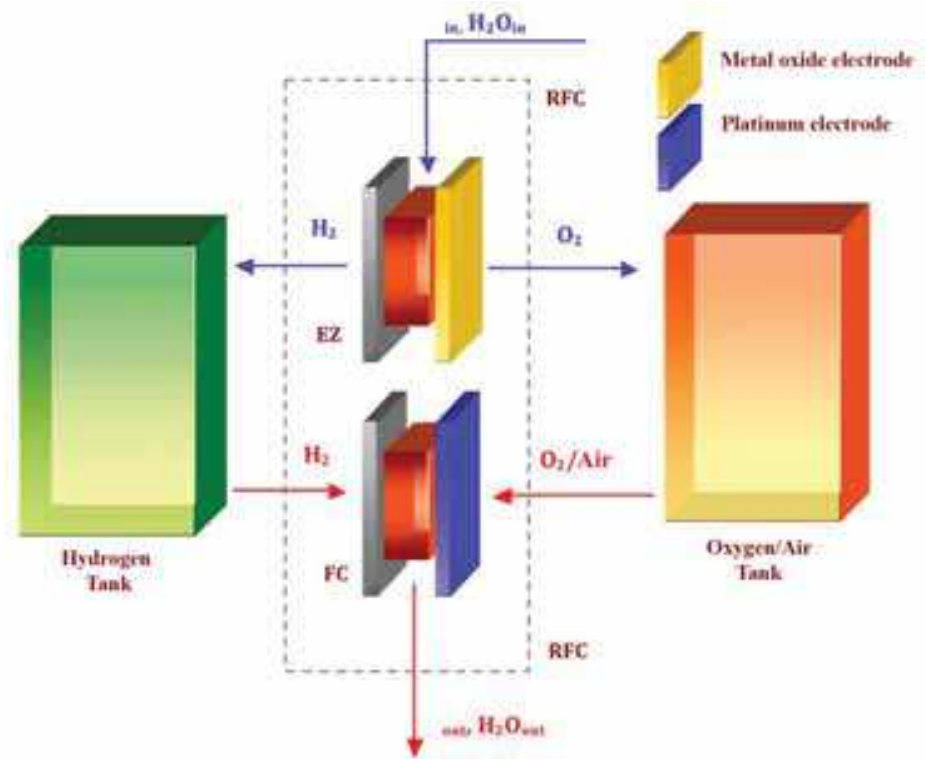

Fig. 6. Regenerative fuel cell (RFC) outline 


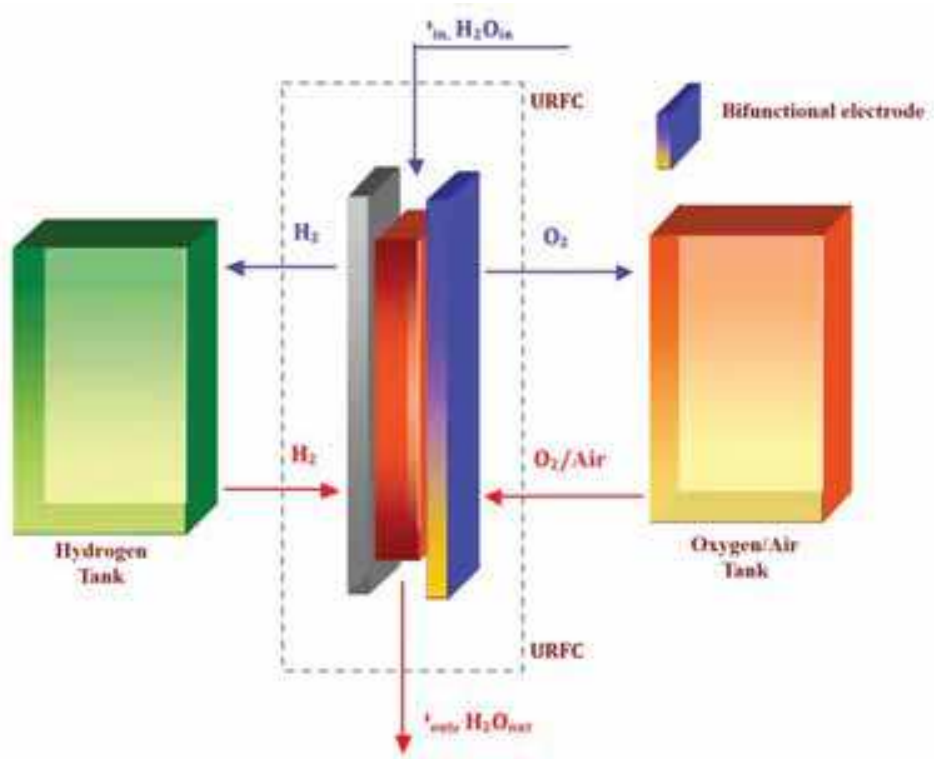

Fig. 7. Unitized regenerative fuel cell outline

\section{Capacitors}

The electrochemical capacitors, or supercapacitors, store energy through ions adsorption at the electrode-electrolyte interface (electrical double layer capacitors) or through redox reactions occurring on the electrode surface (pseudo-capacitors).They can supplement or replace batteries in applications where is necessary supplying or taking up high electrical power. Great performance enhancements have been reached through the recent comprehension of mechanisms of charge accumulation and the development of nanostructured materials. The use of nanomaterials with pseudo-capacitive characteristics, such as oxides, nitrides and polymers, as well as lithium nanostructured electrodes, has raised the energy density of electrochemical capacitors, approaching the values of batteries. The use of carbon nanotubes has allowed the fabrication of electrochemical micro-capacitors much more flexible.

Supercapacitors can be completely charged or discharged in a few seconds; as a consequence, their energy density (about $5 \mathrm{Wh} \mathrm{kg}^{-1}$ ) is lower than that of batteries but the supply or absorption of power is much higher $\left(10 \mathrm{~kW} \mathrm{~kg}^{-1}\right)$ even if for short times (few seconds). Mathematical modelling and simulation will be the key for the future design of devices with high energy and power. Electrochemical capacitors have an important role in supplementing or substituting batteries in some fields of energy storage, such as back-up devices for protection from current interrupting or load levelling. Several types of capacitors have been developed, being different in the mechanism of accumulation charge or active materials used.

Their energy density (about $5 \mathrm{Wh} \mathrm{kg}^{-1}$ ) is lower than that of batteries but the supply or absorption of power is much higher $\left(10 \mathrm{~kW} \mathrm{~kg}^{-1}\right)$ even if for short times (few seconds). 

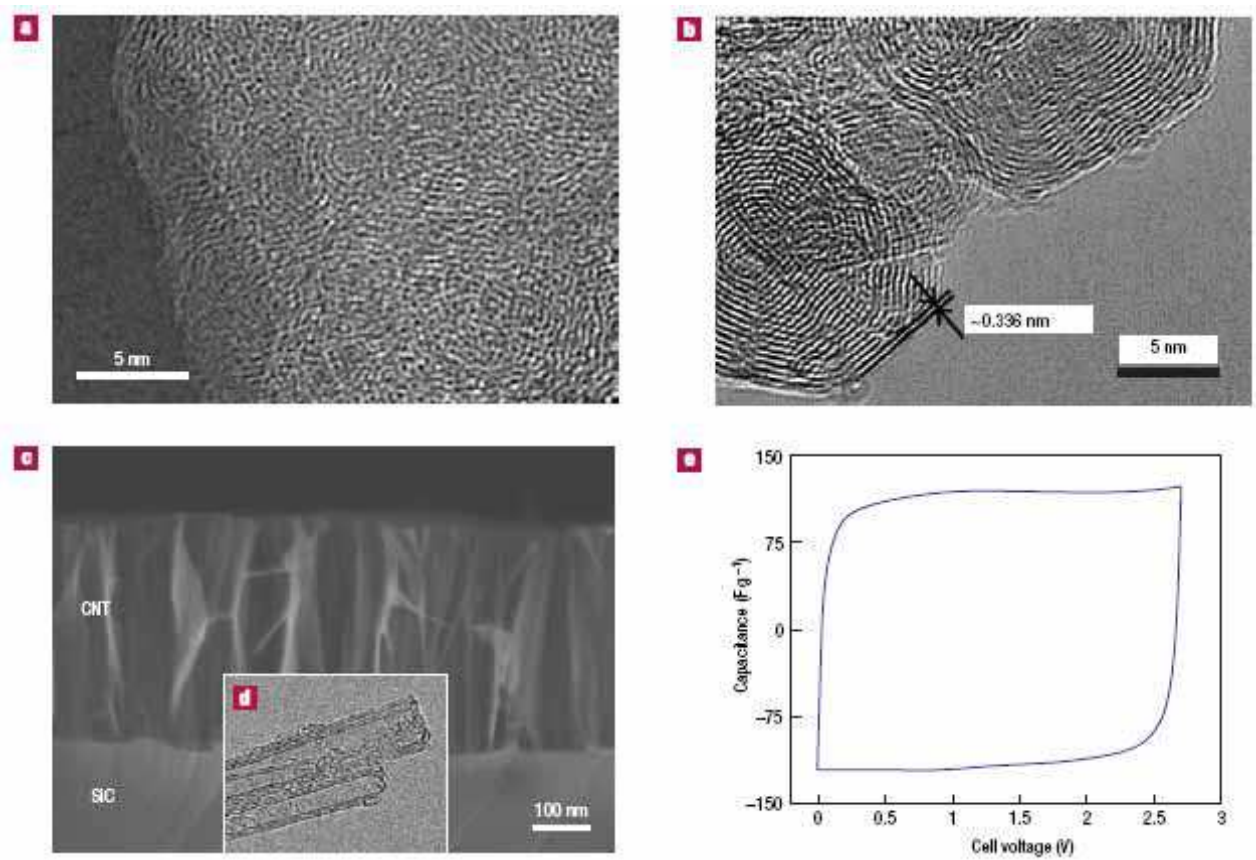

Fig. 8. Carbon structures for double-layer capacitors: a) TEM image of a microporous carbon (SiC-derived, three-hours chlorination at $1000^{\circ} \mathrm{C}$ ); b) TEM image of onion-like carbon (Elsevier, 2007); c) SEM image of $\mathrm{CNT}$ matrix (sinterization at $1700^{\circ} \mathrm{C}$ six hours) on $\mathrm{SiC}$; inset (d): CNT TEM image; e) cyclic voltammetry of a two-electrodes EDLC cell in $1.5 \mathrm{M}$ tetraethylammonium tetrafluoroborate (Net4+BF4) in acetonitrile with active carbon on Alcoated current collectors.

In pseudo-capacitors, or redox supercapacitors, fast redox reactions occur on the surface for charge accumulation. Metal transition oxides and electron conductive polymers are examples of materials with pseudo-capacitive properties. Hybrid capacitors, that combine a capacitive or pseudo-capacitive electrode with a battery-type electrode, take advantage of both capacitor and battery properties.

Electrochemical capacitors bridge the gap between batteries and conventional solid state electrolytic capacitors. They accumulate a charge two-three order of magnitude higher (tens of farad per gram) with respect to the electrolytic capacitor, due to a much more large specific surface (1000-2000 $\left.\mathrm{m}^{2} \mathrm{~g}-1\right)$. Yet, they have a lower energy density with respect to batteries, and this characteristic decrease to less than a minute the discharge time (many applications clearly need energy for a longer time).

\subsection{Mechanism of double-layer capacity}

EDLC are electrochemical capacitors which electrostatically memorize the charge with reversible absorption of electrolyte ions on electrochemically active materials with high 
specific surface area. During polarization, charge separation occurs at the electrodeelectrolyte interface, producing the capacitive double layer (C):

$$
\mathrm{C}=\varepsilon_{\mathrm{r}} \varepsilon_{0} \mathrm{~A} / \mathrm{d} \text { or } \mathrm{C} / \mathrm{A}=\varepsilon_{\mathrm{r}} \varepsilon_{0} / \mathrm{d}
$$

where $\varepsilon_{\mathrm{r}}$ is the electrolyte dielectric constant, $\varepsilon_{0}$ is the vacuum dielectric constant, $\mathrm{d}$ is the actual thickness of double layer (charge separation distance), A is the electrode surface. The double layer capacity is comprised between 5 and 20 microfarad. $\mathrm{cm}^{-2}$ depending upon the electrolyte. The specific capacities obtained with alkaline or acid aqueous solutions are generally higher than those in organic solutions, but organic electrolytes are more widely used because they are able to sustain a higher working voltage (up to $2.7 \mathrm{~V}$ in symmetrical systems). As the stored energy is proportional to the square voltage:

$$
\mathrm{E}=1 / 2 \mathrm{CV}^{2}
$$

a three times increase of $\mathrm{V}$ results in an increase of about one order of magnitude of $\mathrm{E}$ for a capacitor having equal capacity.

The consequence of conservation of the electrostatic charge is that there is not a faradaic reaction (redox) at EDLC electrodes. The electrode of a supercapacitor can be considered as a blocking electrode from the electrochemical point of view. This difference with the batteries means that there is not any limitation by the kinetics of the electrochemical reaction. Furthermore, this accumulation mechanism on the surface allows the fast absorption and the supply of energy, therefore better power performance. The absence of faradaic reactions avoids also the swelling of the active material, as occurs in batteries during the charge/discharge cycles. EDLC are able to sustain billions of cycles, whereas batteries few thousands only. Furthermore, the electrolyte solvent is not involved in the mechanism of charge accumulation, differently from Li-ion batteries that contributes to the formation of the solid-electrolyte interface when graphite anodes or high cathode potentials are used. EDLC can work also at very low temperatures (up to $-40^{\circ} \mathrm{C}$ ) with some particular electrolytes and solvents. Yet, as a consequence of the mechanism of surface electrostatic charge, these devices have a low energy density. This explains because the research is mainly addressed to the improvement of their energy efficiency and to the enlargement of temperature range, where batteries cannot work.

\subsection{Active high surface area (SSA) materials}

The use of blocking, high SSA electrodes and good electronic conductors is the way to obtain high capacities. Graphitic carbon satisfies these requisites. Active carbons, template carbons, as well as carbon tissues, fibres and nanotubes have been largely tested for EDLC applications. Active carbons are today the mostly used because of their high specific surface area (SSA) and low cost.

Active carbons are obtained from carbon-rich organic precursors by thermal treatment in inert atmosphere and subsequent selective oxidation in $\mathrm{CO}_{2}$, water vapour atmosphere or $\mathrm{KOH}$ in order to increase the pore volume and SSA. Natural materials, such as coconut shells, wood, resins, or synthetic materials, such as polymers, can be used as precursors. After activation a porous structure is formed inside the carbon particles, including micropores $(<2 \mathrm{~nm})$, mesopores $(2-50 \mathrm{~nm})$ and macropores $(>50 \mathrm{~nm})$. The average pore 
dimension increases as the activation time or the temperature are increased. The doublelayer capacity of active carbons reaches $100-120 \mathrm{~F} \mathrm{~g}^{-1}$ with organic electrolytes and 150-300 F $\mathrm{g}^{-1}$ in aqueous electrolytes but at a lower cell voltage, because the voltage window of the electrolyte is limited by water decomposition. Carbon nanotubes or nanofibres show lower capacity (50-80 $\mathrm{F} \mathrm{g} \mathrm{g}^{-1}$ ), which can be little increased by functionalization with oxygen-rich surface groups, but their presence decreases the stability capacitor.
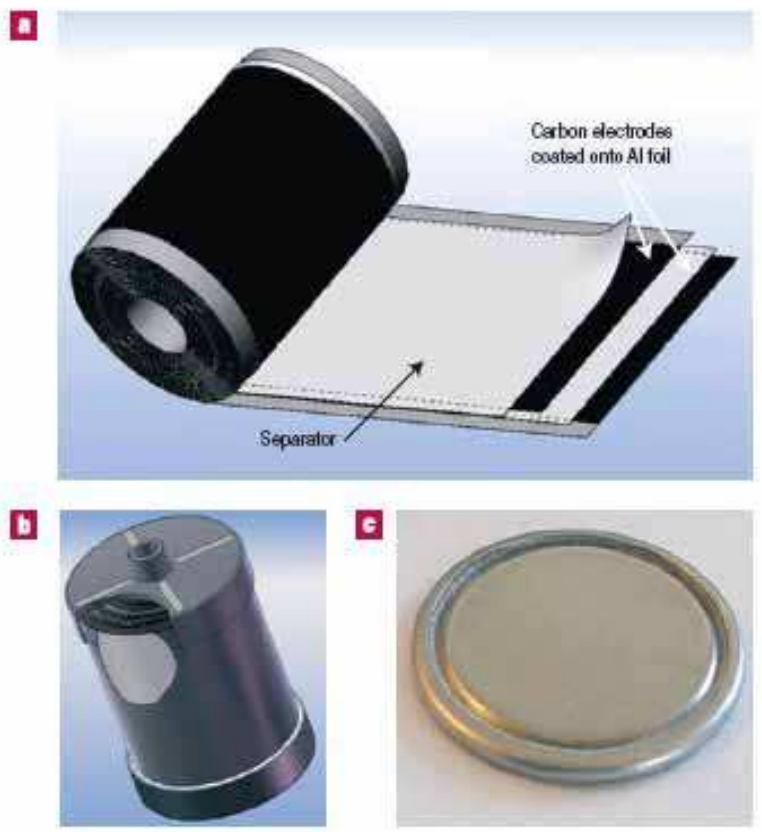

Fig. 9. a) Schematic representation of a double-layer spiral capacitor; b) assembled device (500 grams, 2600 F); Batscap, Groupe Bollorè; c) button cell (1.6 mm height, 5 F capacity); Y-Carbon.

It has been demonstrated that a pore size distribution between 2 and $5 \mathrm{~nm}$ is the more effective in increasing energy and power density, because this range is more accessible to solvated ions.

\subsection{Redox electrochemical capacitors (pseudo-capacitors)}

Pseudo-capacitors make use of fast and reversible reactions on the surface of the active materials, producing the so-called pseudo-capacitive behaviour. Metal oxides, such as $\mathrm{RuO}_{2}$, $\mathrm{Fe}_{3} \mathrm{O}_{4}$ or $\mathrm{MnO}_{2}$, as well as some electron conducting polymers, have been investigated in the last decades. The specific pseudo-capacitance is higher than that of carbons (based on the double-layer charge), and this justifies the interest for such systems. The drawback is that the redox reactions, similarly to what happens in batteries, often reduce the stability during operation.

Ruthenium oxide, $\mathrm{RuO}_{2}$, has been largely investigated, as it is a good electronic conductor and has three distinct oxidation states below $1.2 \mathrm{~V}$. The reversible process can be described 
like a fast electrons transfer together with an electro-absorption of protons on the particle surface of $\mathrm{RuO}_{2}$, where the Ru oxidation states can vary from (II) to (IV):

$$
\mathrm{RuO}_{2}+x \mathrm{H}^{+}+x \mathrm{e}^{-}=\mathrm{RuO}_{2-\mathrm{x}}(\mathrm{OH})_{\mathrm{x}}
$$

Where $x$ is comprised between 0 and 2. The continuous change of $x$ during the entry or the exit of protons occurs in a window potential of about $1.2 \mathrm{~V}$, and leads to a capacitive behaviour with ion absorption of the Frumkin isotherm type. Specific capacities of more than $600 \mathrm{~F} \mathrm{~g} \mathrm{~g}^{-1}$ have been observed. Unfortunately, based-Ru EC are not cheap, and the $1 \mathrm{~V}$ voltage window limits their application to small electronic devices. To increase this value, non-protonic organic electrolytes (for example, $\mathrm{Li}^{+}$containing) could be used. Less expensive are the oxides of iron, vanadium, nickel and cobalt. In particular, Mn oxide has been largely investigated. Its charge accumulation mechanism is based on the surface absorption of the electrolyte cations $\left(\mathrm{K}^{+}, \mathrm{Na}^{+}, \mathrm{H}^{+} \ldots\right)$ according to the reaction:

$$
\mathrm{MnO}_{2}+\mathrm{xC}^{+}+\mathrm{yH}^{+}+(\mathrm{x}+\mathrm{y}) \mathrm{e}^{-}=\mathrm{MnOOC}_{\mathrm{x}} \mathrm{H}_{\mathrm{y}}
$$

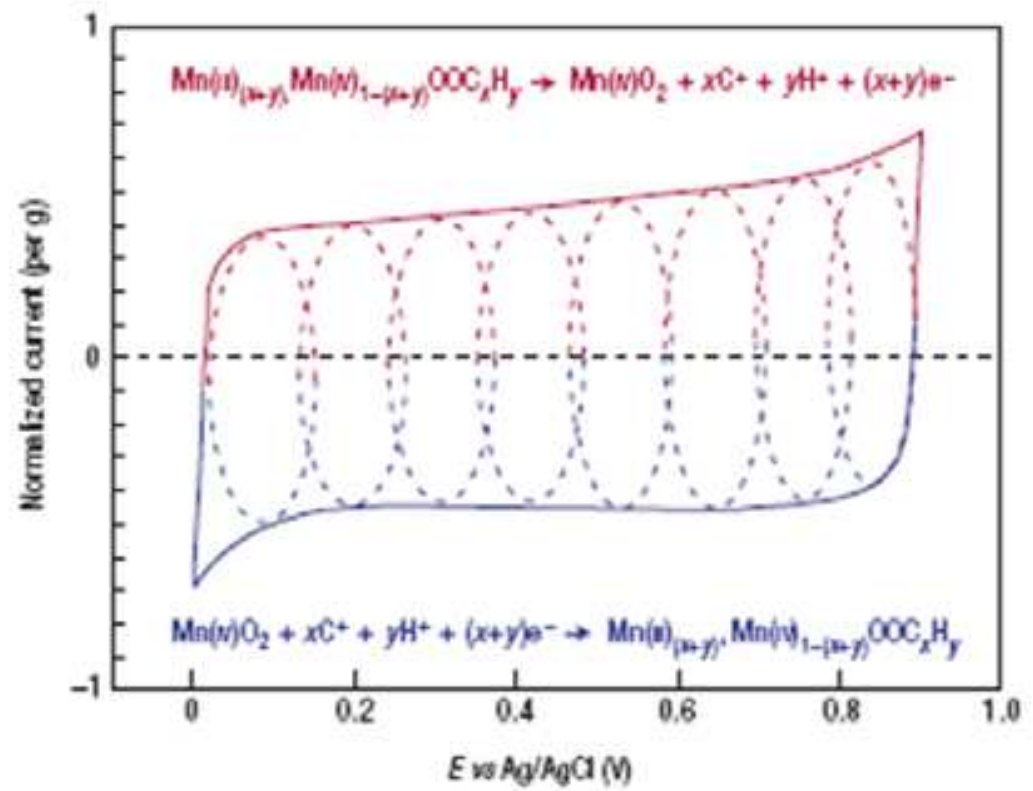

Fig. 10. Voltammogram of a $\mathrm{MnO}_{2}$ electrode in neutral aqueous electrolyte

Fig.10 shows the voltammogram of a $\mathrm{MnO}_{2}$ electrode in neutral aqueous electrolyte; the surface redox reactions (fast, reversible, with a regular sequence) define the voltammogram shape, which appears to be similar to that of ELDC. $\mathrm{MnO}_{2}$ micropowders or micrometric films show capacities of about $150 \mathrm{~F} \mathrm{~g}^{-1}$ in neutral aqueous electrolytes in a voltge range of $1 \mathrm{~V}$, that are appropriate for hybrid systems (see below). 


\subsection{Nanostructured redox materials}

Since in pseudo-capacitors the charge accumulates on the first nanometers of the surface, by reducing the particle dimension the active surface of the material increases. For example, $\mathrm{MnO}_{2}$ and $\mathrm{RuO}_{2}$ films deposited on different supports (metal collectors, carbon nanotubes, active carbon) have shown specific capacitance values higher than $1300 \mathrm{~F} \mathrm{~g}^{-1}$. It has been demonstrated that the synthesis of thin films or the decoration of high SSA capacitive materials with pseudo-capacitive materials increases the energy density.

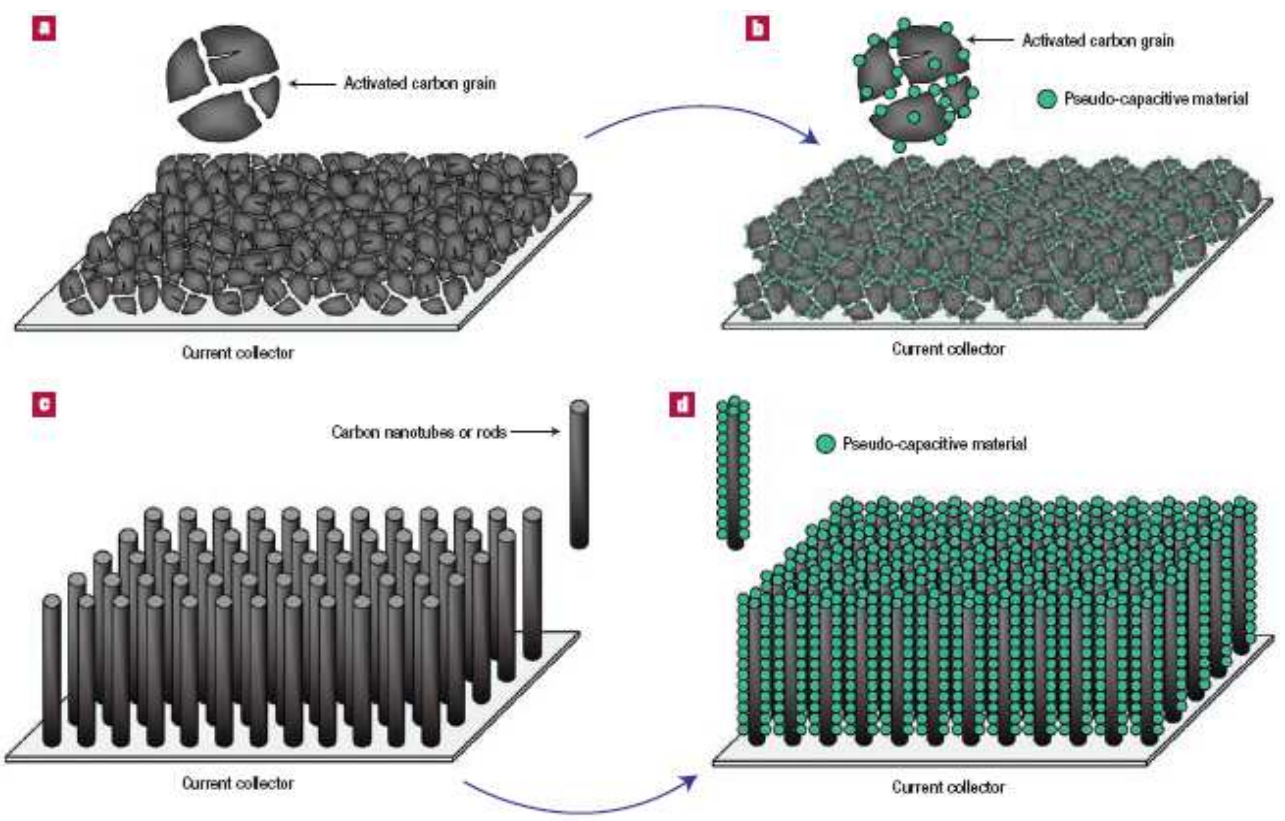

Fig. 11. Possible strategies to enhance energy and specific power of electrochemical capacitors: $a, b$ ) decoration of active carbon grains (a) with pseudo capacitive materials (b). $c, d)$ attainment of an uniform deposit of pseudo-capacitive material (d) on high ordered, high SSA CNT layer (c).

\subsection{Hybrid systems}

Hybrid systems offer a valid alternative to traditional pseudo-capacitors or EDLC, allowing to combine in the same cell one battery-type electrode (energy source) with one capacitortype electrode (power source). At present, two different approaches have been adopted: i) metal oxide electrode having pseudo-capacitive properties with a capacitive carbon electrode and ii) lithium-inserted electrode with capacitive carbon electrode.

Several combinations of positive and negative electrodes have been investigated in aqueous and organic electrolytes. In most cases, the faradic electrode produced an increase in energy density but a decrease in cyclability. This is certainly the main drawback of hybrid devices in comparison with EDLC. 
$\mathrm{MnO}_{2}$ represents a valid alternative to $\mathrm{RuO}_{2}$ due to its low cost. Its pseudo-capacitance originates from the change in oxidation state, III/IV, at the $\mathrm{MnO}_{2}$ particle surface. The association of a negative EDLC-type electrode with a positive $\mathrm{MnO}_{2}$ one produces a $2 \mathrm{~V}$ cell in aqueous electrolyte, thanks to the overvoltage of water decomposition on $\mathrm{MnO}_{2}$ and to the high surface area of carbon. The low cost of the carbon- $\mathrm{MnO}_{2}$ hybrid system, together with the high capacitance in neutral aqueous electrolyte and the high cell voltage, make this system a valid, environmental friendly alternative to EDLC, which use solvents like acetonitrile or fluoride salts. A challenge for these systems is the use of organic electrolytes, in order to reach higher cell voltages, thus improving the energy density.

The combination of a carbon electrode with a $\mathrm{PbO}_{2}$ battery-type one produces a low cost EC for those applications in which weight has a minor role.

Furthermore, several studies have been carried out on different combinations of Li-inserted electrodes with a capacitive carbon electrode. Energy density of over $15 \mathrm{Wh} \mathrm{kg}^{-1}$ and $3.8 \mathrm{~V}$ have been obtained.

\section{Conclusions}

Sustainable distributed power-supply systems are a realistic option to ensure a sustainable, affordable and secure energy supply. Nevertheless, because different renewable energy sources can complement each other, multi-source hybrid alternative energy systems have great potential to provide higher quality and more reliable power to customers than a system based on a single resource, but systemic, technical and institutional adaptations are required for their further development and incorporation in local electricity networks. Understanding the leading storage technologies and how they can affect grid operations is an important first step in this assessment and it is perceived as the pre-condition for extensive development of renewable energy systems. It is increasingly recognized that a large market for distributed energy systems will depend on significant technology advances in energy storage systems but as said above to reach commercialization, both distributed generation and energy storage must address a number of key issues such as lower installed costs, increased lifetime, and low maintenance costs.

\section{References}

Antonucci P.L., Internal Report 003/10/MecMat UniRc, Dept of Mechanics and Materials Mediterranea, University of Reggio Calabria, March 2010.

Antonucci V., Internal Report 006/11/ ITAE, CNR Institute of Advanced Energy Technologies, Messina, January 2011.

Makansi J. \& Abboud J., “Energy Storage”, Energy Storage Council White Paper, May 2002.

Strbac G. \& Black M., DTI, “Review of Electrical Energy Storage Technologies and Systems of their Potential for the UK", London 2004. 
Stuntz L., Electricity Advisory Committee Report,"Bottling Electricity: Storage as a Strategic Tool for Managing Variability and Capacity Concerns in the Modern Grid", 2008.

The Authors are indebted with the copyright holders of the figures included in the chapter for the use without previous permission due to difficulty in tracing their origin. 


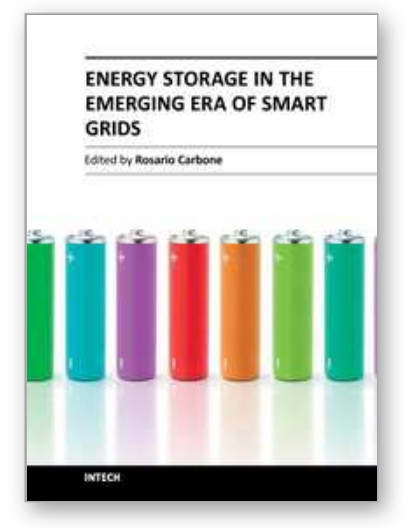

\author{
Energy Storage in the Emerging Era of Smart Grids \\ Edited by Prof. Rosario Carbone
}

ISBN 978-953-307-269-2

Hard cover, 478 pages

Publisher InTech

Published online 22, September, 2011

Published in print edition September, 2011

Reliable, high-efficient and cost-effective energy storage systems can undoubtedly play a crucial role for a large-scale integration on power systems of the emerging â€œdistributed generationâ€ (DG) and for enabling the starting and the consolidation of the new era of so called smart-grids. A non exhaustive list of benefits of the energy storage properly located on modern power systems with DG could be as follows: it can increase voltage control, frequency control and stability of power systems, it can reduce outages, it can allow the reduction of spinning reserves to meet peak power demands, it can reduce congestion on the transmission and distributions grids, it can release the stored energy when energy is most needed and expensive, it can improve power quality or service reliability for customers with high value processes or critical operations and so on. The main goal of the book is to give a date overview on: (I) basic and well proven energy storage systems, (II) recent advances on technologies for improving the effectiveness of energy storage devices, (III) practical applications of energy storage, in the emerging era of smart grids.

\title{
How to reference
}

In order to correctly reference this scholarly work, feel free to copy and paste the following:

Pier Luigi Antonucci and Vincenzo Antonucci (2011). Electrochemical Energy Storage, Energy Storage in the Emerging Era of Smart Grids, Prof. Rosario Carbone (Ed.), ISBN: 978-953-307-269-2, InTech, Available from: http://www.intechopen.com/books/energy-storage-in-the-emerging-era-of-smart-grids/electrochemical-energystorage

\section{INTECH}

open science | open minds

\section{InTech Europe}

University Campus STeP Ri

Slavka Krautzeka 83/A

51000 Rijeka, Croatia

Phone: +385 (51) 770447

Fax: +385 (51) 686166

www.intechopen.com

\section{InTech China}

Unit 405, Office Block, Hotel Equatorial Shanghai

No.65, Yan An Road (West), Shanghai, 200040, China

中国上海市延安西路65号上海国际贵都大饭店办公楼 405 单元

Phone: +86-21-62489820

Fax: $+86-21-62489821$ 
(C) 2011 The Author(s). Licensee IntechOpen. This chapter is distributed under the terms of the Creative Commons Attribution-NonCommercialShareAlike-3.0 License, which permits use, distribution and reproduction for non-commercial purposes, provided the original is properly cited and derivative works building on this content are distributed under the same license. 